\title{
ОСОБЛИВОСТІ СХРЕЩУВАННЯ М'ЯКОЇ ПШЕНИЦІ ТА ЖИТА ЗАЛЕЖНО ВІД ДІЇ РІЗНИХ ДОЗ ГАММА-ПРОМЕНІВ
}

О. В. Панкова, В. К. Пузік

Харківський національний аграрний університет ім. В. В. Докучаєва

У роботі наведено результати вивчення схрещуваності м'якої пшениці і жита залежно від дії гамма-променів на насіння материнської форми, дози опромінення, вибору материнської форми при схрещуваннях і комбінації схрещувань. Показана ефективність дії на насіння материнської форми гамма-променів у дозі 150 Гр у всіх комбінаціях схрещування. Отримано дані, які свідчать, що для схрещуваності пшениці і жита характерна сортова специфічність. Найкращі результати отримано при використанні в якості материнської форми сорту Харківська 26, та батьківської - жита сорту Gazelle.

Тверда і м'яка пшениия, жито, віддалена гібридизація, схрещування, гібридна зернівка, мутагенез, гамма-промені.

Однією з провідних проблем біологічної науки сучасності є збагачення флори і фауни методом створення нових форм і сортів рослин, які найбільш повно відповідають запитам людини. Важливе значення у вирішенні цих завдань належить віддаленій гібридизації, методу, який дозволяє значно збагатити генофонд культурних рослин і створити особливо широкий формотворчий процес, при якому виникають унікальні форми, які значно відрізняються від тих, що існували раніше [7]

У реалізації можливостей віддаленої гібридизації найбільші труднощі викликають бар'єри репродуктивної несумісності, стерильність і понижена життєздатність гамет і зигот [10]. Серед численних факторів, що зумовлюють несумісність при віддалених схрещуваннях, В. П. Баннікова [2] виділяє два найбільш жорстких бар'єра несхрещуваності. Вони приурочені до етапу зростання пилкових трубок у стовпчику та етапу формування насіння. E. East висловив гіпотезу, згідно з якою подолання зростання пилкових трубок пояснюється виникненням імунологічної реакції за принципом антиген - антитіло [14]. Для пояснення біохімічної природи несумісності Д. Льюїсом запропонована «димерна» гіпотеза [16]. Згідно цієї гіпотези в пилкової трубки і маточки утворюються димери - поліпептиди, що складаються 3 двох білкових ланцюгів. Реакція несумісності включається при проростанні пилку шляхом об'єднання димерів у тетра-

(C) О. В. Панкова, В. К. Пузік. 2012.

ISSN 0582-5075. Селекція і насінництво. 2012. Випуск 102. 
мери. Тетрамер, будучи ферментом, починає діяти на зростання пилкових трубок шляхом пригнічення синтезу ростових речовин, або індукуючи синтез інгібіторів. На думку В. П. Піддубної-Арнольді [9], несумісність при віддалених схрещуваннях зумовлена відсутністю запліднення, загибеллю на ранніх стадіях проростання насіння гібридних зародків і ендосперму або на стадії проростання насіння.

Пошук шляхів, які будуть сприяти підвищенню частоти зав'язуваності гібридних зернівок та покращення їх життєздатності при схрещуванні різних видів пшениці і жита має особливе значення. Несумісність різних видів, що приймають участь у схрещуваннях, можна подолати, використовуючи різноманітні методи.

Метою нашої роботи було дослідити вплив різних доз опромінення на схрещуваність злаків. Враховуючи велику роль материнського організму при формуванні зернівки, зроблена спроба підвищити зав язуваність зернівок при гібридизації м якої пшениці з житом шляхом дії на материнський організм гамма-опроміненням.

Матеріали та методи. Насіння сортів різних видів пшениці перед посівом обробляли гамма-променями, джерелом яких був ${ }^{60} \mathrm{Co}$, на установці «Theratron Elit-80» (інтенсивність випромінювача $7442 \mathrm{Ku}$ ). Доза при опроміненні насіння становила 100 Гр, 150 Гр, 200 Гр, 250 Гр. Як контроль використовували насіння без обробки.

Об'єктами досліджень були представники родини Poaceae: Triticum aestivum L. $(2 \mathrm{n}=42)$; Secale cereale L. $(2 \mathrm{n}=14)$. Види злаків, які використовувалися в експериментах, представлені сортами ярої м'якої пшениці Героїня, Харківська 6, Харківська 26. Яре жито у дослідах представлено сортами Gazelle, Rogo.

Польові досліди проводили у 2008-2010 рр. на дослідному полі Харківського національного аграрного університету ім. В. В. Докучаєва. Посів проводили вручну. Площа ділянки $1 \mathrm{~m}^{2}$, повторність 4-х кратна. Ділянки, розміщували у повтореннях систематичним методом. По досягненні рослинами фази колосіння проводили схрещування [6]. Для цього квітки і колосся кастрували звичайним способом за 2-3 дні до цвітіння. На кожному варіанті каструвалося по 800 квіточок щорічно. Запилення обмежено-примусове, на 3-4 день після кастрації переважно в ранковий час. Обмолот колосків проводили вручну. Для інтерпретації одержаних результатів використовували трьохфакторний дисперсійний аналіз [1] 3 використанням стандартного пакету статистики в Microsoft Excel. У таблицях представлені середні арифметичні та достовірні інтервали при рівні значущості 0,05 .

Результати та їх обговорення. Аналіз отриманих нами результатів, наведених у табл. 1 показав, що зав'язуваність гібридних зернівок залежить від дози гамма-опромінення. Найкращі результати отримано при дії на насіння материнської форми гамма-променів у дозі 150 Гр у всіх комбінаціях схрещування. При дозі 100 Гр спостерігається підвищення зав'язуваності, яке досягає максимуму при дозі 150 Гр. При дозі 200 Гр спостерігається 
зниження зав'язуванності гібридних зернівок, яке досягає мінімуму при дії гамма-опромінення в дозі 250 Гр. Така закономірність спостерігалась нами незалежно від вибору сорту і комбінації схрещування.

Таблиця 1

Зав язуваність гібридних зернівок при схрещуванні різних сортів м'якої пшениці (Tr. aestivum L.) і жита залежно від $\gamma$-опромінення

(середне за 2008 - 2010 pp)

\begin{tabular}{|c|c|c|c|c|c|c|c|}
\hline \multirow{2}{*}{\multicolumn{2}{|c|}{$\begin{array}{l}\text { Варіант } \\
\text { досліду }\end{array}$}} & \multicolumn{2}{|c|}{ Комбінація схрещувань } & \multicolumn{4}{|c|}{$\begin{array}{c}\text { Зав язуваність зернівок } \\
\text { за роки, \% }\end{array}$} \\
\hline & & $\begin{array}{c}\text { материнська } \\
\text { форма }\end{array}$ & $\begin{array}{c}\text { батьківська } \\
\text { форма }\end{array}$ & 2008 & 2009 & 2010 & середнє \\
\hline \multicolumn{2}{|l|}{1} & 2 & 3 & 4 & 5 & 6 & 7 \\
\hline \multicolumn{2}{|c|}{$\begin{array}{l}\text { Насіння без } \\
\text { обробки (контроль) }\end{array}$} & \multirow{5}{*}{ Героїня } & \multirow{5}{*}{ Gazelle } & 6,3 & 3,5 & 1,5 & 3,8 \\
\hline \multirow{4}{*}{$\begin{array}{l}\text { Оброблено } \\
\gamma \text {-променями в } \\
\text { дозі (Гр) }\end{array}$} & 100 & & & 9,3 & 6,8 & 2,8 & 6,3 \\
\hline & 150 & & & 12,8 & 10,0 & 5,8 & 9,5 \\
\hline & 200 & & & 7,8 & 3,5 & 3,8 & 5,0 \\
\hline & 250 & & & 1,5 & 1,3 & 1,0 & 1,3 \\
\hline \multicolumn{2}{|c|}{$\begin{array}{l}\text { Насіння без } \\
\text { обробки (контроль) }\end{array}$} & \multirow{5}{*}{$\begin{array}{l}\text { Харків- } \\
\text { ська } 28\end{array}$} & \multirow{5}{*}{ Gazelle } & 4,8 & 3,5 & 1,8 & 3,3 \\
\hline \multirow{4}{*}{$\begin{array}{l}\text { Оброблено } \\
\gamma \text {-променями в } \\
\text { дозі (Гр) }\end{array}$} & 100 & & & 8,0 & 5,5 & 2,8 & 5,4 \\
\hline & 150 & & & 11,5 & 7,8 & 4,8 & 8,0 \\
\hline & 200 & & & 9,5 & 6,0 & 3,8 & 6,4 \\
\hline & 250 & & & 1,5 & 1,3 & 0,8 & 1,2 \\
\hline \multicolumn{2}{|c|}{$\begin{array}{l}\text { Насіння без } \\
\text { обробки (контроль) }\end{array}$} & \multirow{5}{*}{$\begin{array}{l}\text { Харків- } \\
\text { ська } 26\end{array}$} & \multirow{5}{*}{ Gazelle } & 6,5 & 5,5 & 3,3 & 5,1 \\
\hline \multirow{4}{*}{$\begin{array}{l}\text { Оброблено } \\
\gamma \text {-променями в } \\
\text { дозі (Гр) }\end{array}$} & 100 & & & 10,0 & 6,8 & 5,0 & 7,3 \\
\hline & 150 & & & 13,0 & 10,0 & 5,8 & 9,6 \\
\hline & 200 & & & 9,8 & 5,3 & 5,3 & 6,8 \\
\hline & 250 & & & 2,5 & 2,0 & 1,0 & 1,8 \\
\hline \multicolumn{2}{|c|}{$\begin{array}{l}\text { Насіння без } \\
\text { обробки (контроль) }\end{array}$} & \multirow{5}{*}{ Героїня } & \multirow{5}{*}{ Rogo } & 3,5 & 3,5 & 1,0 & 2,7 \\
\hline \multirow{4}{*}{$\begin{array}{l}\text { Оброблено } \\
\text { ү-променями в } \\
\text { дозі (Гр) }\end{array}$} & 100 & & & 7,0 & 4,8 & 2,3 & 4,7 \\
\hline & 150 & & & 9,8 & 9,3 & 5,0 & 8,0 \\
\hline & 200 & & & 6,3 & 3,8 & 2,8 & 4,3 \\
\hline & 250 & & & 1,5 & 1,8 & 1,0 & 1,4 \\
\hline \multicolumn{2}{|c|}{$\begin{array}{l}\text { Насіння без } \\
\text { обробки (контроль) }\end{array}$} & \multirow{5}{*}{$\begin{array}{l}\text { Харків- } \\
\text { ська } 28\end{array}$} & \multirow{5}{*}{ Rogo } & 3,3 & 3,0 & 1,0 & 2,4 \\
\hline \multirow{4}{*}{$\begin{array}{l}\text { Оброблено } \\
\gamma \text {-променями } \\
\text { в дозі (Гр) }\end{array}$} & 100 & & & 6,3 & 4,3 & 2,3 & 4,3 \\
\hline & 150 & & & 9,8 & 7,0 & 3,8 & 6,8 \\
\hline & 200 & & & 7,3 & 4,8 & 2,8 & 4,9 \\
\hline & 250 & & & 1,3 & 1,3 & 1,0 & 1,2 \\
\hline
\end{tabular}


Продовження табл. 1

\begin{tabular}{|c|c|c|c|c|c|c|c|}
\hline \multicolumn{2}{|c|}{1} & 2 & 3 & 4 & 5 & 6 & 7 \\
\hline \multicolumn{2}{|c|}{$\begin{array}{l}\text { Насіння без } \\
\text { обробки (контроль) }\end{array}$} & \multirow{5}{*}{$\begin{array}{l}\text { Харків- } \\
\text { ська } 26\end{array}$} & \multirow{5}{*}{ Rogo } & 6,5 & 4,3 & 2,5 & 4,4 \\
\hline \multirow{4}{*}{$\begin{array}{l}\text { Оброблено } \\
\gamma \text {-променями } \\
\text { в дозі (Гр) }\end{array}$} & 100 & & & 9,0 & 5,8 & 4,0 & 6,3 \\
\hline & 150 & & & 11,8 & 7,8 & 4,5 & 8,0 \\
\hline & 200 & & & 8,5 & 2,5 & 5,0 & 5,8 \\
\hline & 250 & & & 1,8 & 1,0 & 0,5 & 1,1 \\
\hline
\end{tabular}

\begin{tabular}{|c|c|c|c|c|c|c|}
\hline \multirow[t]{7}{*}{ Примітка } & $\mathrm{HIP}_{05}(\mathrm{~A})$ & 0,78 & $\mathrm{HIP}_{05}(\mathrm{~A})$ & 0,69 & $\mathrm{HIP}_{05}(\mathrm{~A})$ & 0,54 \\
\hline & $\mathrm{HIP}_{05}$ (B) & 0,63 & $\mathrm{HIP}_{05}(\mathrm{~B})$ & 0,56 & $\mathrm{HIP}_{05}$ (B) & 0,44 \\
\hline & $\mathrm{HIP}_{05}(\mathrm{C})$ & 1,00 & $\mathrm{HIP}_{05}(\mathrm{C})$ & 0,89 & $\mathrm{HIP}_{05}(\mathrm{C})$ & 0,70 \\
\hline & $\mathrm{HIP}_{05}(\mathrm{AB})$ & 1,10 & $\mathrm{HIP}_{05}(\mathrm{AB})$ & 0,98 & $\mathrm{HIP}_{05}(\mathrm{AB})$ & 0,76 \\
\hline & $\mathrm{HIP}_{05}(\mathrm{AC})$ & 1,74 & $\mathrm{HIP}_{05}(\mathrm{AC})$ & 1,55 & $\mathrm{HIP}_{05}(\mathrm{AC})$ & 1,21 \\
\hline & $\mathrm{HIP}_{05}(\mathrm{BC})$ & 1,42 & $\mathrm{HIP}_{05}(\mathrm{BC})$ & 1,26 & $\mathrm{HIP}_{05}(\mathrm{BC})$ & 0,98 \\
\hline & $\begin{array}{l}\text { HIP } 05 \\
(\mathrm{ABC})\end{array}$ & 2,46 & $\begin{array}{l}\mathrm{HIP}_{05} \\
(\mathrm{ABC})\end{array}$ & 2,19 & $\begin{array}{l}\mathrm{HIP}_{05} \\
(\mathrm{ABC})\end{array}$ & 1,70 \\
\hline
\end{tabular}

Причинами зниження зав'язуваності гібридних зернівок при збільшенні дози опромінення, на нашу думку, можуть бути ускладнення у структурній і функціональній перебудові клітини, які виникають при збільшенні дози опромінення $[8,13]$. Процес реплікації ДНК пригнічується радіацією у зв'язку з блокуванням ініціації реплікації, а також розпадом ДНК - білкових комплексів. При дії великих доз уражається структура і функції геному [3]. У зв'язку з цим можливо припустити, що доза 250 Гр повністю блокує процеси розмноження клітини пшениці.

Зав'язуваність гібридних зернівок залежить від вибору материнської форми при схрещуваннях і комбінації схрещування (табл. 1). Найкращі результати отримано при використанні в якості материнської форми сорту Харківська 26, як в комбінації схрещування Харківська 26 х Gazelle, так і в комбінації схрещування Харківська 26 х Rogo. Дещо нижчі результати спостерігались нами при використанні в якості материнської форми сорту Героїня. Використання сорту Харківська 28 в якості материнської форми привело до зниження зав'язуваності гібридних зернівок.

Аналіз результатів отриманих по комбінаціях схрещувань показав, що зав'язуваність гібридних зернівок $є$ кращою в комбінації схрещувань $T r$. aestivum x Gazelle. Використання в якості батьківської форми сорту жита Rogo приводить до зниження зав'язуваності гібридних зернівок. Можливо, це пов'язано зі здатністю батьківського генотипу жита частково інгібіювати ефект домінантних $\mathrm{Kr}$-генів несумісності материнських рослин пшениці у про- та постгамний періоди, що призводить до підвищення схрещуваності $[4,11,12]$. Ці гени впливають на характер росту пилкових трубок у тканинах приймочки материнської рослини, знижуючи зав'язуваність гібридних зернівок [15]. 
Той факт, що для схрещуваності пшениці і жита характерна сортова специфічність, на нашу думку, пояснюється наступним. На рівні виду існує генетична єдність, яка виявляється у корінних суттєвих ознаках - тотожністю за складом і послідовністю розташування у хромосомах генних локусів та ї кластерів. Активність різноманітних процесів в організмі тісно пов'язана зі структурним і функціональним станом геному, хромосом, їх сегментів та окремих локусів [5]. Саме як цілісна єдність вид зберігається, еволюціонує на основі генетичної специфічності, тобто відмінності від інших видів. Також специфічність характерна і для сортів, оскільки процеси запліднення проходять під генетичним контролем, а він $є$ специфічним для виду і сорту, тому вірогідно, що і схрещуваність характеризується видовою і сортовою специфікою.

За допомогою трьохфакторного дисперсійного аналізу (рис. 1) було показано, що доза гамма-опромінення (фактор С) мала визначальну дію на зав'язуваність гібридних зернівок при схрещуванні різних видів пшениці ярої з житом ярим - частка впливу фактора $\mathrm{C}$ в комбінації схрещування T. aestivum / S. cereale складала 55\%.

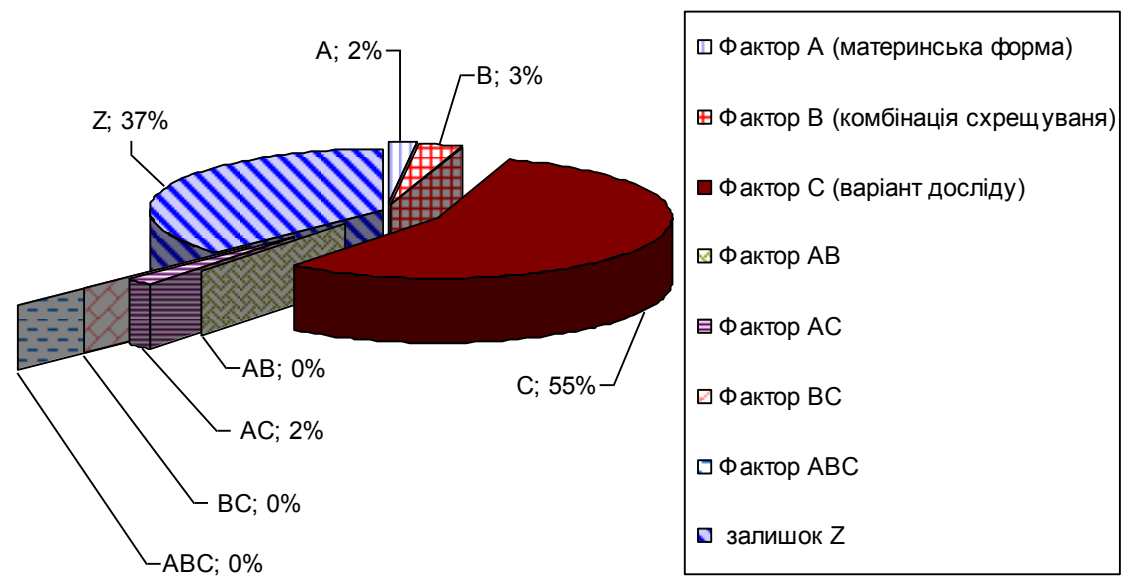

Рис. 1. Частка впливу факторів на схрещуваність у комбінації схрещування T. aestivum / S. cereale, \%

Вибір материнської форми (фактор А) та комбінації схрещувань (фактор В) незначимі, так як залишкова дисперсія значно більше факторної дисперсії (рис. 1). Так, частка впливу факторів у комбінації схрещування T. aestivum / S. cereale у середньому за роки проведення дослідів становила: фактор (А) - 2,0 \%; фактор (В) - 3,0\%. Взаємодія факторів (АВ) становила $0 \%$, взаємодія факторів (АС) - $2 \%$, взаємодія факторів $(\mathrm{BC})-0 \%$, взаємодія факторів (ABC) - 0\%, залишок (Z) - 37\% (рис. 1). 
Як відомо [1], залишкова (внутрішньогрупова) дисперсія (фактор Z) характеризує розсіювання варіант всередині груп. Варіантами в нашому випадку є показники за трьома роками дослідів, тобто можливо констатувати різницю між результатами трьох років дослідів. Це пояснюється залежністю від погодних умов, які в роки дослідів були різними. 2008 рік в цілому був сприятливим для росту і розвитку рослин, тоді як 2009 та 2010 характеризувались підвищеною температурою повітря та малою кількістю опадів, що призвело до запізнення вегетації та пригніченню рослин.

Висновки. Таким чином, результати проведених досліджень свідчать, що дія гамма-опромінення за певних доз на насіння материнської форми підвищує схрещуваність пшениці ярої з житом і залежить не тільки від сорту і комбінації схрещування, а і від дози опромінення. За допомогою трьохфакторного дисперсійного аналізу було показано, що доза гаммаопромінення мала визначальну дію на зав'язуваність гібридних зернівок. Найкращі результати отримано при дії на насіння материнської форми гамма-променів у дозі 150 Гр у всіх комбінаціях схрещування, при використанні в якості материнської форми сорту Харківська 26, та батьківської жита сорту Gazelle.

\section{Список використаних джерел}

1. Атраментова Л. А. Статистические методы в биологии / Л. А. Атраментова, О. М Утевская. - Горловка:ЧП «Видавництво Ліхтар», 2008. - 248 с.

2. Банникова В. П. Цитоэмбриология межвидовой несовместимости у растений / В. П.Банникова - Киев: Наукова думка, 1975. - 283 с.

3. Винокурова Л. В. Генетичні і цитологічні прояви реакції тритікале та його вихідних форм на гамма-опромінення повітряно-сухого насіння: автореф. ...канд. біол. наук: 03.00.15 / Л. В. Винокурова. - Харківський державний університет. - Х., 1996. - 17 стр.

4. Гордей И. А. Генетические основы повышения скрещиваемости мягкой пшеницы (Triticum aestivum L.) с культурной рожью (Secale cerale L.). Полиморфизм озимой ржи по степени совместимости с пшеницей / И. А. Гордей, Г. М. Гордей // Генетика. - 1992. - Т. 28., №2. - С.137-142.

5. Конарев В. Г. Морфология и молекулярно-биологический анализ растений / Василий Григорьевич Конарев. - Спб.: ВИР, 1998. - 370 с.

6. Коновалов Ю. Б. Практикум по селекции и семеноводству полевіх культур / Ю. Б. Коновалов, А. Н. Березкин, Л .И. Долгодворова - М.: Высшая школа, 1973. - 367 с.

7. Котальникова Л. К. Создание нового исходного материала в селекции тритикале / Л. К.Котальникова, П. И. Буюкли, Е. К. Веверица // Генетика и селекция тритикале в Молдове. - Кишенев: Штиинца, 1992. $-165 \mathrm{c}$.

8. Моргун В. В. Мутационная селекция пшеницы / В. В.Моргун, 
В. Ф. Логвиненко - К.: Наукова думка, 1995. - 626 с.

9. Поддубная - Арнольди В. А. Цитоэмбриология покрытосеменных растений / В. А. Поддубная - Арнольди. - М.: Наука, 1976. - 482 с.

10. Пузік В. К. Екзометаболіти культурних злаків та їх роль у фітоценозах / В. К. Пузік, Г. Ф. Наумов. - Наук. видання: Харк. нац. аграр. ун-т ім. В.В. Докучаєва. -Х., 2003. - 296 с.

11. Рябчун В. К. Создание яровых тритикале методом сложной межродовой гибридизации: дис.... канд. биол. наук. : спец. 03.00.15 "Генетика", 06.01.05 "Селекция и семеноводство" / Виктор Кузьмич Рябчун. - НИИ растениеводства им. В. Я. Юрьева, Харьков, 1986. - 169 с.

12. Таврин Э. В. Влияние генов скрещиваемости на завязываемость семян при гибридизации мягкой пшеницы с однозернянкой / Э. В. Таврин, М. Х. Ибрагимова // Частная генетика растений. - Т. 2. - Киев, 1990. C. 90 .

13. Таирбеков М. Г. Структурные и функциональные аспекты устойчивости растительной клетки / М. Г. Таирбеков // Успехи современной биологии. - 1973. - Т. 75. - № 3. - С. $406-418$.

14. East E. M. Self - sterility / E. M. East // Bibliographia Genetica - 1929. V. 5. - P.331-370.

15. Jalani B. S. The effects of species, polyploidy and embryo transplantation on the crosabillity between Triticum and Secale / B. S. Jalani, H.- L. Moss // Pflanzenzucht, 1981. - 86. - № 4. - P. 286-297.

16. Lewis D. Unilateral interspecific incompatibility in flowering plants / D. Lewis, L. K. Crowe // Heredity. - 1958. - V. 12. - P. 233.

В статье приводятся результаты исследований скрещиваемости разных видов пшеницы в зависимости от действия гамма-лучей на материнскую форму, их дозы, выбора материнской формы при скрещиваниях и комбинациях скрещиваний.

Crossing of different types of wheat and barley depending on operating of gamma-rays on a maternal plant has been studied in this article. The results which were get, ground to suppose that receipt of hybrid weevils is depending on the choice of maternal plant, and also from weather terms. The most percent of crossing was got in combinations of crossing, where as a maternal form a hard wheat was used, and in the variants of irradiation 100, $150 \mathrm{Gr}$. 